\title{
A multicenter, retrospective analysis of elderly patients Research Paper myeloid leukemia who were treated with decitabine
}

\author{
Jun Ho Yí ${ }^{1}$, Silvia Park², Jung Han Kim³ ${ }^{3}$ Young-Woong Won ${ }^{4}$, Do Hyoung Lim ${ }^{5}$, \\ Boram Han ${ }^{6}$, Jieun Uhm ${ }^{7}$, Hae Su Kim${ }^{8}$, Chul Won Jung' ${ }^{2}$ and Jun Ho Jang ${ }^{2}$ \\ ${ }^{1}$ Division of Hematology-Oncology, Department of Medicine, Chung-Ang University Hospital, Seoul, Korea \\ ${ }^{2}$ Division of Hematology-Oncology, Department of Medicine, Samsung Medical Center, Sungkyunkwan University School of \\ Medicine, Seoul, Korea \\ ${ }^{3}$ Department of Internal Medicine, Kangnam Sacred-Heart Hospital, Hallym University Medical Center, Hallym University \\ College of Medicine, Seoul, Korea \\ ${ }^{4}$ Division of Hematology and Oncology, Department of Internal Medicine, Hanyang University Guri Hospital, Hanyang \\ University College of Medicine, Guri, Korea \\ ${ }^{5}$ Department of Internal Medicine, Dankook University College of Medicine, Cheonan, Korea \\ ${ }^{6}$ Department of Internal Medicine, Hallym University Medical Center, Hallym University, Hallym University College of Medicine, \\ Anyang, Korea \\ ${ }^{7}$ Division of Hematology and Oncology, Department of Internal Medicine, Hanyang University Seoul Hospital, Hanyang \\ University College of Medicine, Seoul, Korea \\ ${ }^{8}$ Division of Hematology-Oncology, Department of Internal Medicine, VHS Medical Center, Seoul, Korea \\ Correspondence to: Jun Ho Jang, email: junhojang@skku.edu
}

Keywords: acute myeloid leukemia; elderly patients; decitabine

Received: February 10, $2017 \quad$ Accepted: December 26, $2017 \quad$ Published: January 02, 2018

Copyright: $\mathrm{Yi}$ et al. This is an open-access article distributed under the terms of the Creative Commons Attribution License 3.0 ( CC BY 3.0), which permits unrestricted use, distribution, and reproduction in any medium, provided the original author and source are credited.

\section{ABSTRACT}

Decitabine is widely accepted as the treatment options for elderly acute myeloid leukemia (AML) patients. However, the efficacy has yet been assessed in Asian population. We retrospectively analyzed the outcomes of $\mathbf{8 0}$ Korean elderly AML patients who were treated with decitabine. The median age was 74 years (range, 64 to 86 years) and $6(7.5 \%), 48(60.0 \%)$, and $25(31.3 \%)$ patients were categorized to favorable, intermediate, and poor risk group, respectively. The median os was 10.2 months (95\% CI 5.0-15.4). Given that decitabine treatment demonstrated improved clinical outcomes, it could be considered as one of the first-line treatment for Korean elderly AML patients.

\section{INTRODUCTION}

Acute myeloid leukemia (AML) is the most common type of leukemia in adults, with more than 12,000 people are diagnosed annually in the United States [1]. Basically, AML is a disease of the elderly as the median age of the newly diagnosed patients is over 65 years [2]. However, the treatment options for the elderly AML patients have been limited, and they usually show poor clinical outcomes owing to their poor performance, comorbidity, unfavorable cytogenetics, or prior hematologic neoplasms. Thus, age per se is considered as one of the major prognostic factors. Although several studies have suggested that elderly AML patients still benefit from intensive chemotherapy [3], a substantial portion of the patients are not suitable for intensive treatment, and there have been unmet needs for this large population.

While various pathways are known to be involved in the development of myeloid neoplasms, recently, epigenetic changes have been turned out to play important roles in leukemogenesis [4]. Decitabine (5-aza-2'-deoxycytidine, Dacogen $^{\circledR}$ ) which inhibits DNA methyltransferase, demonstrated promising results in patients with highrisk myelodysplastic syndrome $[5,6]$. With these results, two prospective trials in elderly AML patients had been conducted which showed improved clinical outcomes 
and acceptable safety profiles compared to conventional treatments $[7,8]$. Based on these data, the use of decitabine in elderly AML patients is approved by the European Committee.

Meanwhile, the superiority of decitabine over conventional treatment was not widely accepted as US FDA rejected its use in elderly AML patients. Furthermore the efficacy or safety of this agent has not been evaluated in Asian population where difference of clinical manifestation or cytogenetics had been noted $[9,10]$. In the current study, we conducted a multicenter, retrospective analysis on elderly AML patients from 8 tertiary institutes in Korea who were treated with decitabine in order to confirm whether the clinical outcomes of this agent are also acceptable in this population, and to provide further understanding of the disease nature of AML arisen in elderly patients.

\section{MATERIALS AND METHODS}

\section{Patients}

Patients diagnosed with AML from 2013 to 2016 were included in the analysis. The inclusion criteria were as follows: (1) 65 or older patients with newly diagnosed, histologically confirmed AML (myeloid blast $\geq 20 \%$ either in the bone marrow or peripheral blood); (2) Treated with decitabine in a schedule of $20 \mathrm{mg} / \mathrm{m}^{2}$ for five days every 4 weeks in patients with adequate organ functions determined by physicians in charge. Of note, patients with acute promyelocytic leukemia, central nervous involvement, or other active systemic malignancies were excluded.

Prior anti-leukemic treatments were not allowed other than cytoreductive hydroxyurea. Clinical parameters including age, sex, performance status, cytogenetic [11]/molecular [12] risk group, baseline laboratory findings, treatment outcomes were collected retrospectively from patients' medical records. Follow-up bone marrow biopsies and aspirations were performed at the discretion of the attending physicians. Prophylactic antibiotics, antifungals, or antivirals were administered following the standard protocols of the institutes. The institutional review boards of all participating centers approved the study.

\section{Statistical analysis}

The primary end-point of the study was OS which was measured from the date of diagnosis of an AML to the date of death or last follow-up using the KaplanMeier method. OS was compared using a log-rank test. Secondary end-point was complete response rate. $P$-values $<0.05$ were considered statistically significant, and all $P$-values corresponded to two-sided significance tests. Statistical analysis was performed using SPSS software version 17.0.

\section{RESULTS}

\section{Patient characteristics}

A total of 80 patients were eligible for the analysis. The median age of patients was 74 years (range, 64 to 86 years) and 49 patients $(61.3 \%)$ were male. All patients were Korean. Regarding the risk group, 6 (7.5\%), 49 $(61.2 \%)$, and $25(31.3 \%)$ cases were classified as favorable, intermediate, and poor risk group, respectively. None of the patients had undergone hematopoietic stem cell transplantation. Other details including performance scale and baseline laboratory findings are described in Table 1.

\section{Clinical outcomes of decitabine treatment}

With the median follow-up duration being 19.6 months (95\% confidence interval (CI) 15.2-24.0), the patients had received median 3 (range 1-27) cycles of treatment. Among 80 patients, only 35 (43.8\%) had been evaluated bone marrow response, and complete remission was noted in 10 patients. The major reasons of not undergoing bone marrow evaluation were inadequate hematologic response of peripheral blood and poor performance status.

The median OS for all patients was 10.2 months (95\% CI 5.0-15.4) (Figure 1), and the 1-year survival rate was $38.3 \%$. The median OS durations according to the cytogenetic risk group are as follows; 12.4 months (95\% CI 11.4-13.4) for favorable risk group $(N=6), 13.6$ months (95\% CI 8.7-18.5) for intermediate risk group $(N=49)$, and 5.5 months (95\% CI 1.4-9.6) for poor risk group $(N=25)(p=.001)$. Another prognostic factor was Eastern Cooperative Oncology Group performance scale (ECOG-PS). When we categorized our cohort into two groups, that is ECOG-PS 0 2 vs. ECOG-PS $3 \& 4$, those with good performance status demonstrated improved survival (11.5 months (95\% CI 6.6-16.4) vs. 4.4 months (95\% CI 2.4-6.4), $p=.004$ ). The OS curves according to prognostic factors are provided in Figure 2. Other clinical factors such as age, sex, bone marrow blast percentage, or white blood cell count did not discriminate patients' outcome (Table 2).

In terms of infectious adverse events, 13 (29.5\%) out of 44 patients who had received at least 3 cycles of treatment have experienced at least 1 infectious adverse events during the first 100 days of treatment. Eight patients had bacterial infections, 3 had fungal infections, and 2 had infections with multiple etiologies.

\section{DISCUSSION}

In the present study, we retrospectively analyzed 80 elderly patients with AML who were treated with decitabine at a schedule of $20 \mathrm{mg} / \mathrm{m}^{2}$ for 5 days every 4 weeks. Decitabine was well tolerated, and patients 
Table 1: Baseline characteristics of the patients $(N=80)$

\begin{tabular}{|c|c|}
\hline Characteristics & $N(\%)$ \\
\hline $\begin{array}{l}\text { Age, years } \\
\text { Median (range) } \\
70 \text { or younger } \\
\text { Older than } 70\end{array}$ & $\begin{array}{c}74(65-86) \\
22(27.5) \\
58(72.5)\end{array}$ \\
\hline $\begin{array}{l}\text { Sex } \\
\quad \text { Male } \\
\text { Female }\end{array}$ & $\begin{array}{l}49(61.2) \\
31(38.8)\end{array}$ \\
\hline $\begin{array}{l}\text { Risk group } \\
\text { Favorable } \\
\text { Intermediate } \\
\text { Poor } \\
\text { Unknown }\end{array}$ & $\begin{array}{c}6(7.5) \\
48(60.0) \\
25(31.3) \\
1(1.2)\end{array}$ \\
\hline $\begin{array}{l}\text { ECOG }^{*} \text { performan } \\
0 \\
1 \\
2 \\
3 \\
4\end{array}$ & $\begin{aligned} 1 & (1.3) \\
11 & (13.8) \\
31 & (38.8) \\
31 & (38.8) \\
6 & (7.5)\end{aligned}$ \\
\hline $\begin{array}{l}\text { Type of AML } \\
\text { De novo } \\
\text { Secondary } \\
\text { Unknown }\end{array}$ & $\begin{array}{l}43(53.7) \\
22(27.5) \\
15(18.8)\end{array}$ \\
\hline $\begin{array}{c}\text { Bone marrow blast } \\
\text { Median (range) }\end{array}$ & $45.7(14.0-99.0)$ \\
\hline $\begin{array}{l}\text { Peripheral blood bl } \\
\text { Median (range) }\end{array}$ & $41.0(0.0-96.0)$ \\
\hline $\begin{array}{l}\text { White blood cells } \\
\text { Median (range) }\end{array}$ & $11,000(200-253,910)$ \\
\hline $\begin{array}{l}\text { Hemoglobin }(\mathrm{g} / \mathrm{dL}) \\
\text { Median (range) }\end{array}$ & $8.1(3.2-16.9)$ \\
\hline $\begin{array}{l}\text { Platelet (/ } \mu \ell \mathrm{L}) \\
\text { Median (range) }\end{array}$ & $56,000(3,000-890,000)$ \\
\hline
\end{tabular}

*ECOG, Eastern Cooperative Oncology Group.

received a median of 3 cycles of treatment with the median OS being 10.2 months. The subset analyses have shown that cytogenetics and ECOG-PS were prognostic factors. About one thirds of patients had experienced infectious adverse events during the first 100 days.

AML is the most common form of acute leukemia in adults. While the 5-year survival rate for patients less than 65 years was $39.5 \%$, that of patients over 65 years was $5.2 \%$ [13]. Intensive chemotherapy can be applied for selected patients with good performance status and favorable cytogenetics, which may result in prolonged survival [14]. For patients who are unlikely to benefit from the intensive treatment, several less-intensive treatment options have been introduced, such as hydroxyurea or lowdose cytarabine (LDAC). Recently, two hypomethylating agents have been introduced in the treatment of elderly AML patients $[8,15,16]$, and among them, in Korea, decitabine is the only agent that was approved and reimbursed for elderly AML patients.

While various doses and schedules have been evaluated, the efficacy and safety of current standard dose and schedule, that is, $20 \mathrm{mg} / \mathrm{m}^{2}$ daily for 5 days every 4 weeks, were evaluated in two studies. In a phase II study of Cashen et al., 55 patients with AML older than 60 years were treated with decitabine. The overall response rate was $25 \%$ and the median overall survival was 7.7 months with the 30-day mortality rate being 7\% [7]. A subsequent phase III trial named DACO-106 was carried out in 485 patients with AML of intermediate or poor risk cytogenetics older than 65 years and they were randomized to receive 
Table 2: Univariate analysis for overall survival (months)

\begin{tabular}{|c|c|c|c|}
\hline & $\boldsymbol{N}$ & $\begin{array}{c}\text { Overall survival } \\
(95 \% \mathrm{CI})\end{array}$ & $p$ \\
\hline $\begin{array}{l}\text { Age } \\
70 \text { or younger } \\
\text { Older than } 70\end{array}$ & $\begin{array}{l}22 \\
58\end{array}$ & $\begin{array}{c}10.8(2.0-19.6) \\
8.3(2.7-13.9)\end{array}$ & .963 \\
\hline $\begin{array}{l}\text { Sex } \\
\quad \text { Male } \\
\text { Female }\end{array}$ & $\begin{array}{l}49 \\
31\end{array}$ & $\begin{array}{c}6.2(0.5-11.9) \\
15.4(5.9-24.9)\end{array}$ & .396 \\
\hline $\begin{array}{l}\text { Risk group }(N=79) \\
\text { Favorable } \\
\text { Intermediate } \\
\text { Poor }\end{array}$ & $\begin{array}{c}6 \\
48 \\
25\end{array}$ & $\begin{array}{c}12.4(11.4-13.4) \\
13.6(8.7-18.5) \\
5.5(1.4-9.6)\end{array}$ & .006 \\
\hline $\begin{array}{l}\text { ECOG }^{*} \text { performance scale } \\
0 \sim 2 \\
3 \sim 4\end{array}$ & $\begin{array}{l}43 \\
37\end{array}$ & $\begin{array}{c}11.5(6.6-16.4) \\
4.4(2.4-6.4)\end{array}$ & .004 \\
\hline $\begin{array}{l}\text { Bone marrow blast percentage }(N=77) \\
\quad 20 \sim 30 \% \\
31 \text { or higher } \%\end{array}$ & $\begin{array}{l}28 \\
49\end{array}$ & $\begin{array}{c}6.4(3.9-8.9) \\
10.2(3.4-16.8)\end{array}$ & .652 \\
\hline $\begin{array}{l}\text { White blood cells }(/ \mu \ell \mathrm{L}) \\
\sim 20,000 \\
20,001 \sim\end{array}$ & $\begin{array}{l}50 \\
30\end{array}$ & $\begin{array}{c}6.4(0.7-12.1) \\
11.5(5.8-17.2)\end{array}$ & .536 \\
\hline
\end{tabular}

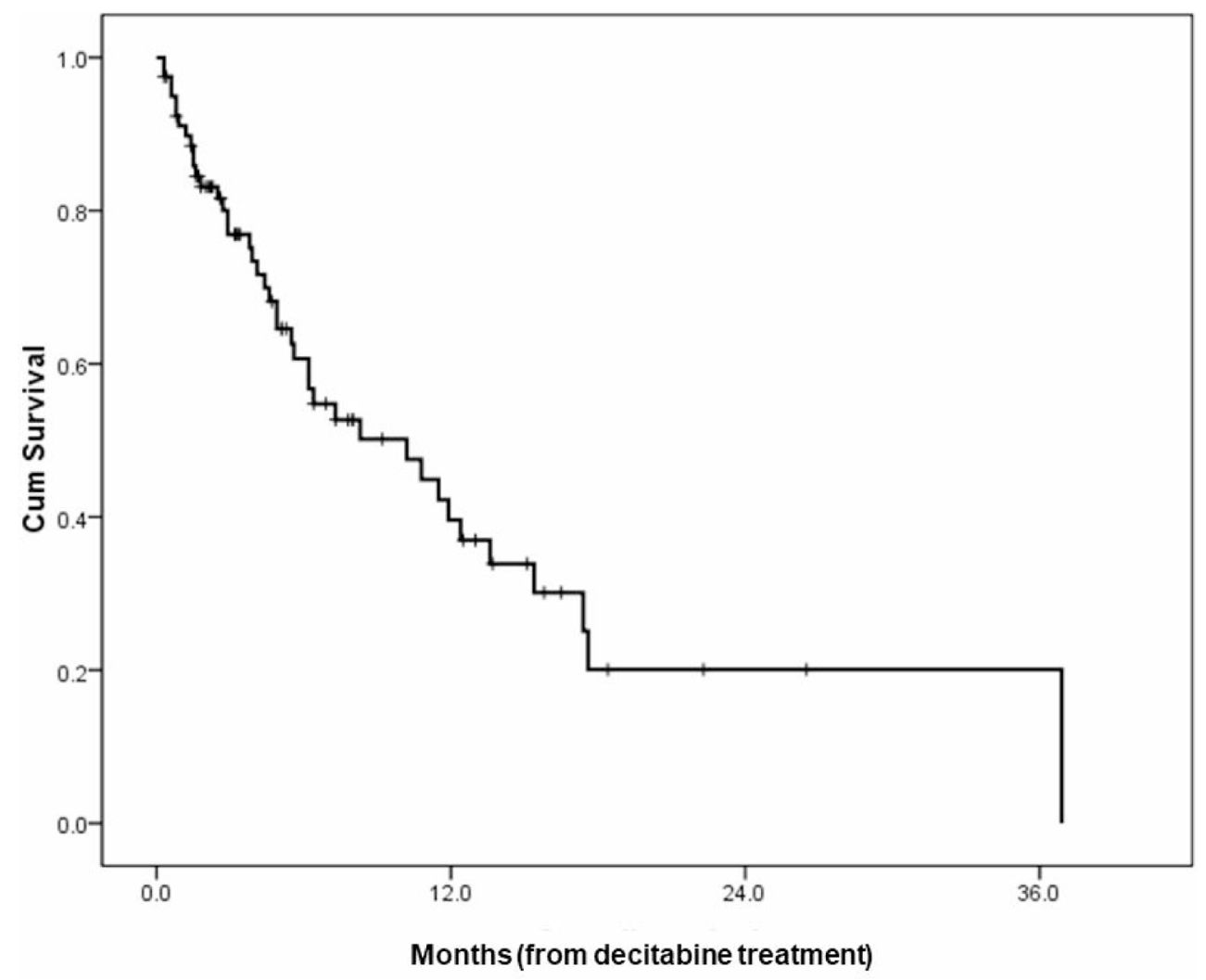

Figure 1: An overall survival curve of all patients. 
either decitabine or physician's choice (best supportive care, BSC or LDAC) [8]. With the median age of the patients being 73 years, decitabine was associated with non-significant but favorable trend of increased OS (7.7 months vs. 5.0 months, $p=.108$, hazard ratio 0.85 (95\% CI 0.69-1.04)), and an unplanned analysis performed after 1 year demonstrated the significant survival benefit $(7.7$ months vs. 5.0 months, $p=.0 .37$, hazard ratio $0.82(95 \% \mathrm{CI}$ 0.68-0.99)). Remission rate was also higher in decitabine arm, as it was associated with a significantly higher rate $(17.8 \%$ vs. $7.8 \%$, respectively, $p=.001)$. However, there were several criticisms regarding the results. First, significant survival benefit was demonstrated only after additional, unplanned analysis. Second, the clinical outcomes with LDAC were unsatisfactory compared to prior studies. Third, there was a regional variation in survival as the majority of benefit was noted in confined to Eastern European patients. And one of the reasons we carried out the current analysis was because just small number of Asian patients were included in the DACO-016 trial, it was necessary to assess the efficacy of decitabine in Asian elderly patients.
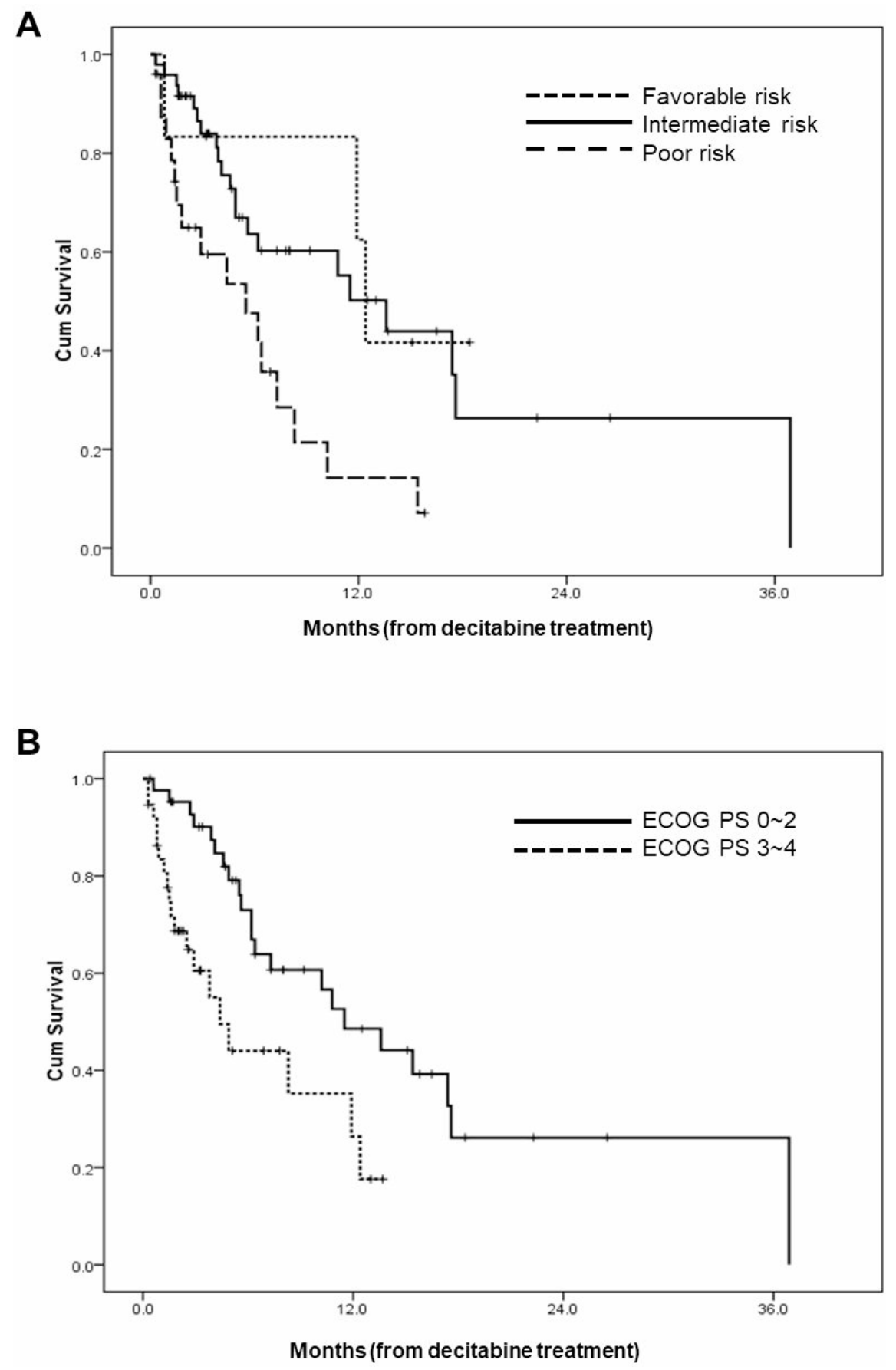

Figure 2: Overall survival curves according to (A) cytogenetic/molecular risk groups; (B) performance scales. 
Table 3: Comparison of the Korean retrospective analysis and the current study

\begin{tabular}{|c|c|c|c|}
\hline & $\begin{array}{c}\text { Best supportive care } \\
(N=\mathbf{2 1 1})\end{array}$ & $\begin{array}{l}\text { The current study } \\
\qquad(N=80)\end{array}$ & $\begin{array}{c}\text { Intensive chemotherapy } \\
\qquad(N=\mathbf{2 6 6})\end{array}$ \\
\hline Age (median, range) & $72(60-101)$ & $74(64-86)$ & $66(60-86)$ \\
\hline Age $>70$ years $(N, \%)$ & $126(59.7)$ & $58(72.5)$ & $52(19.5)$ \\
\hline $\begin{array}{l}\text { Performance }(N, \%) \\
0 \\
1 \\
2 \\
3 \\
4\end{array}$ & $\begin{array}{c}2(0.9) \\
53(25.1) \\
56(26.5) \\
18(8.5) \\
3(1.4)\end{array}$ & $\begin{aligned} 1 & (1.3) \\
11 & (13.8) \\
31 & (38.8) \\
31 & (38.8) \\
6 & (7.5)\end{aligned}$ & $\begin{array}{c}12(4.5) \\
110(41.4) \\
46(17.3) \\
9(3.4) \\
0(0.0)\end{array}$ \\
\hline $\begin{array}{l}\text { Risk group }(N, \%) \\
\text { Favorable } \\
\text { Intermediate } \\
\text { Poor } \\
\text { Unknown }\end{array}$ & $\begin{array}{c}7(3.3) \\
115(54.5) \\
44(20.9) \\
45(21.3)\end{array}$ & $\begin{array}{c}6(7.5) \\
48(60.0) \\
25(31.3) \\
1(1.2)\end{array}$ & $\begin{array}{c}12(4.5) \\
163(61.3) \\
55(20.7) \\
36(13.5)\end{array}$ \\
\hline $\begin{array}{l}\text { Median OS (days), } \\
(95 \% \text { CI) }\end{array}$ & & & \\
\hline $\begin{array}{l}\text { Age } \\
\quad 60 \sim 65 \\
66 \sim 70 \\
71 \sim 75 \\
76 \sim\end{array}$ & $\begin{array}{c}56(20.8-91.2) \\
67(13.8-120.2) \\
116(44.2-187.8) \\
83(35.5-130.5)\end{array}$ & $\begin{array}{c}302(181.9-506.9) \\
129(73.3-184.3) \\
322(136.4-507.6) \\
179(8.5-349.9)\end{array}$ & $\begin{array}{c}346(222.8-469.2) \\
316(209.1-422.9) \\
332(138.9-525.1) \\
78(0-610.4)\end{array}$ \\
\hline $\begin{array}{l}\text { Performance } \\
\text { (median, 95\% CI) } \\
0 \\
1 \\
2 \\
3 \\
4\end{array}$ & $\begin{array}{c}7 \\
116(48.7-183.3) \\
85(4.7-165.3) \\
62(20.6-103.4) \\
18\end{array}$ & $\begin{array}{c}\mathrm{N} / \mathrm{A} \\
487(0-1086.4) \\
302(166.0-453.8) \\
232(66.6-398.2) \\
25(5.0-45.4)\end{array}$ & $\begin{array}{c}308(0-697.8) \\
427(310.9-543.1) \\
332(196.1-467.9) \\
22(0-63.6) \\
\text { N/A }\end{array}$ \\
\hline $\begin{array}{l}\text { Risk group }(N, \%) \\
\text { Favorable } \\
\text { Intermediate } \\
\text { Poor }\end{array}$ & $\begin{array}{c}190(27.8-352.2) \\
101(48.4-153.6) \\
45(23.9-66.1)\end{array}$ & $\begin{array}{c}347.2(319.2-375.2) \\
380.8(243.6-518.0) \\
154(39.2-268.8)\end{array}$ & $\begin{array}{c}\text { N/A } \\
392(297.6-486.4) \\
239(118.2-359.8)\end{array}$ \\
\hline Overall & $86(54-118)$ & $285.6(140-431.2)$ & $339(275-403)$ \\
\hline
\end{tabular}

OS, overall survival; N/A, not available; $\mathrm{CI}$, confidence interval.

The decision of the front-line treatment for elderly AML patients is a challenging issue. To evaluate the efficacy of decitabine compared to BSC or intensive chemotherapy in elderly AML patients, we compared our data to the data of a study by Kim et al. [17], in which retrospective analyses of 477 Korean elderly AML patients who were treated with either BSC or intensive chemotherapy were undertaken (Table 3). In terms of patient characteristics, our cohort is consisted of older patients, and the proportion of poor performance/cytogenetics was higher in our cohort. The comparison of survival data, however, demonstrated interesting findings. The OSs of BSC group, our cohort, and intensive chemotherapy group were 86 days $(95 \% \mathrm{CI}$ 54-118), 286.6 days (140-431.2), and 339 days (275-403), respectively. Although it is not a head-to-head comparison, it seems that OS of our cohort is quiet better than that of BSC group. While the numerical data are superior in intensive chemotherapy group, their younger age and better performance status may have contributed to it. Subset analyses showed similar findings. Compared to the BSC group, the survival outcomes of our cohort are better, in the same age, performance scale, and cytogenetic risk groups. Compared to intensive chemotherapy group, the numerical data are slightly inferior in many fields but the difference is not a big number and besides, in a few fields like age over 76 years or ECOS-PS 3, OS was superior in our cohort. Although it is difficult to make a firm conclusion with these results, our data may imply that decitabine treatment should be considered for these patients. Further investigations, including prospective clinical trials are required. 
Table 4: Comparison of the DACO-016 study and the current study

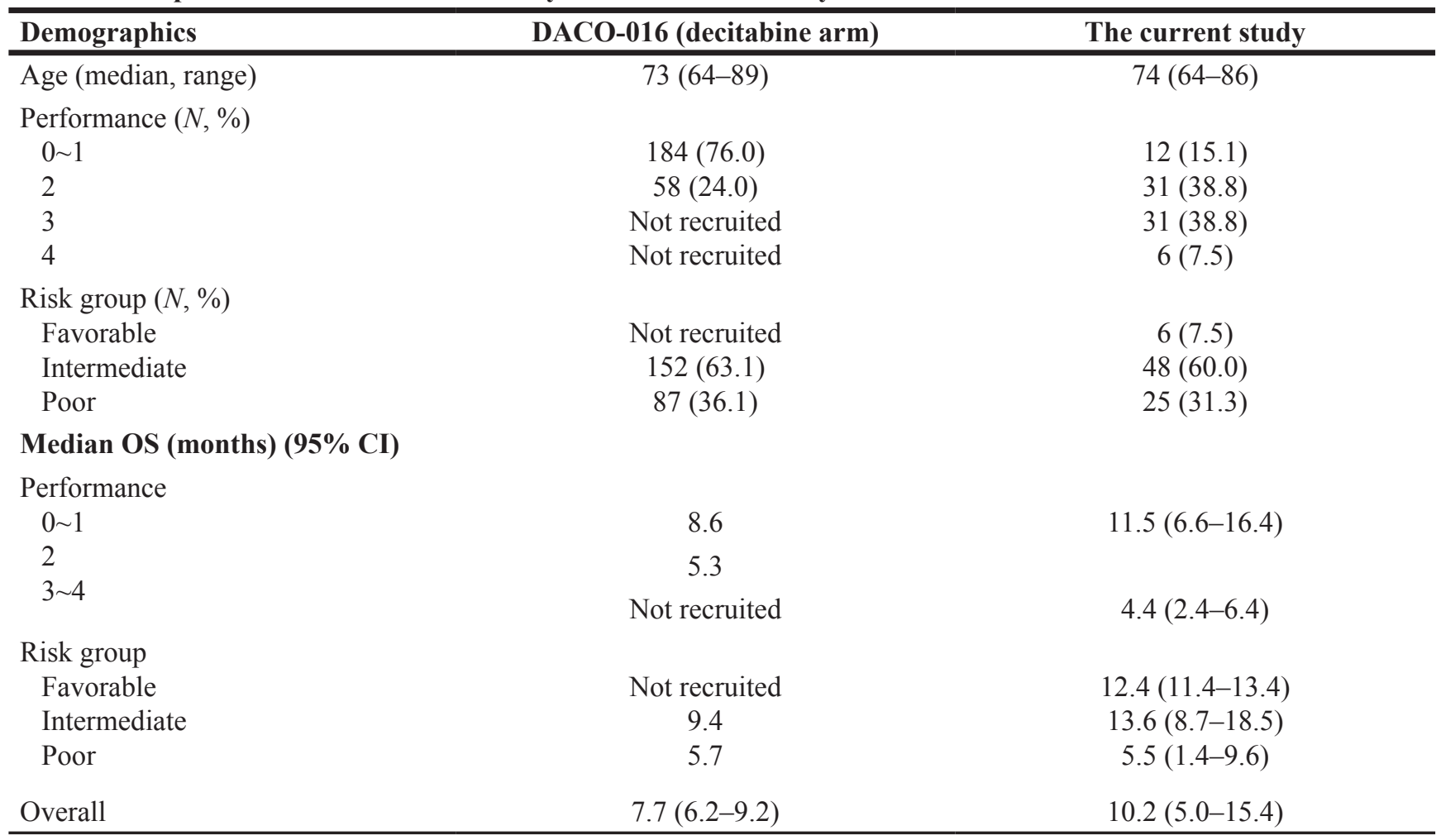

We could find a couple of interesting findings out of the comparison of the DACO-016 trial and the current study (Table 4). While the median age and the distribution of risk group of the patients were similar, the DACO-016 trial had more patients with better performance, as they did not recruited patients with ECOG-PS 3 or 4. However, the median OS was longer in our cohort (10.2 months vs. 7.7 months). And again, when we compare these two data at the same ECOG-PS or risk groups, it seems that outcomes of our cohort is better, which may suggest ethnic difference of efficacy of decitabine treatment. In fact, in the DACO-016 trial, for a small subset of Asian patients who were allocated to decitabine $\operatorname{arm}(N=27)$, the OS was 9.3 months which was the best among the whole regional subgroups (North America 6.0, Eastern Europe 6.7, and Western Europe 9.0 months). Future analysis will be needed to determine how racial differences affect outcomes of decitabine treatment.

The current study has several limitations. Data were collected in a retrospective manner and from multiple centers. However, as we assessed OS, we believe the validity of the conclusive data and rather, it may reflect real world clinical outcomes. In addition, we could not provide the data for subsequent treatment after decitabine failure. Even if there is no known effective treatment after decitabine failure, overall survival could have been affected by the subsequent therapy. And the subsequent bone marrow examinations were performed in only 35 $(43.8 \%)$ patients which may hinder to assess response rate. As the patients were old and in poor performance status, it was difficult to perform subsequent bone marrow examinations. In fact, in the DACO-016 trial, out of 485 patients, 132 patients $(27.2 \%)$ did not undergo bone marrow evaluation. And in the real world situation, as there are no effective second-line treatment options for these patients, clinicians may be reluctant to perform bone marrow examinations. And, as we focused on the efficacy of the treatment, the current study does not provide detailed safety profiles other than infectious events.

\section{CONCLUSIONS}

While the treatment options for elder AML patients have been limited, our real world data suggest that decitabine could be an effective treatment of choice, especially in Korean patients.

\section{CONFLICTS OF INTEREST}

The authors declare that they have no conflict of interest.

\section{FUNDING}

This Research was supported by the Chung-Ang University Research Grants in 2017.

\section{REFERENCES}

1. Juliusson G, Lazarevic V, Horstedt AS, Hagberg O, Hoglund M. Acute myeloid leukemia in the real world: 
why population-based registries are needed. Blood. 2012; 119:3890-9. https://doi.org/10.1182/blood-2011-12-379008.

2. Sekeres MA, Stone RM. The challenge of acute myeloid leukemia in older patients. Curr Opin Oncol. 2002; 14:24-30.

3. Juliusson G, Antunovic P, Derolf A, Lehmann S, Mollgard L, Stockelberg D, Tidefelt U, Wahlin A, Hoglund M. Age and acute myeloid leukemia: real world data on decision to treat and outcomes from the Swedish Acute Leukemia Registry. Blood. 2009; 113:4179-87. https://doi.org/10.1182/ blood-2008-07-172007.

4. Ley TJ, Miller C, Ding L, Raphael BJ, Mungall AJ, Robertson A, Hoadley K, Triche TJ Jr, Laird PW, Baty JD, Fulton LL, Fulton R, Heath SE, et al, and Cancer Genome Atlas Research Network. Genomic and epigenomic landscapes of adult de novo acute myeloid leukemia. $\mathrm{N}$ Engl J Med. 2013; 368:2059-74. https://doi.org/10.1056/ NEJMoa1301689.

5. Kantarjian H, Issa JP, Rosenfeld CS, Bennett JM, Albitar M, DiPersio J, Klimek V, Slack J, de Castro C, Ravandi F, Helmer R 3rd, Shen L, Nimer SD, et al. Decitabine improves patient outcomes in myelodysplastic syndromes: results of a phase III randomized study. Cancer. 2006; 106:1794-803. https://doi.org/10.1002/cncr.21792.

6. Lubbert M, Suciu S, Baila L, Ruter BH, Platzbecker U, Giagounidis A, Selleslag D, Labar B, Germing U, Salih HR, Beeldens F, Muus P, Pfluger KH, et al. Low-dose decitabine versus best supportive care in elderly patients with intermediate- or high-risk myelodysplastic syndrome (MDS) ineligible for intensive chemotherapy: final results of the randomized phase III study of the European Organisation for Research and Treatment of Cancer Leukemia Group and the German MDS Study Group. J Clin Oncol. 2011; 29:1987-96. https://doi.org/10.1200/ jco.2010.30.9245.

7. Cashen AF, Schiller GJ, O'Donnell MR, DiPersio JF. Multicenter, phase II study of decitabine for the first-line treatment of older patients with acute myeloid leukemia. J Clin Oncol. 2010; 28:556-61. https://doi.org/10.1200/ jco.2009.23.9178.

8. Kantarjian HM, Thomas XG, Dmoszynska A, Wierzbowska A, Mazur G, Mayer J, Gau JP, Chou WC, Buckstein R, Cermak J, Kuo CY, Oriol A, Ravandi F, et al. Multicenter, randomized, open-label, phase III trial of decitabine versus patient choice, with physician advice, of either supportive care or low-dose cytarabine for the treatment of older patients with newly diagnosed acute myeloid leukemia. J Clin Oncol. 2012; 30:2670-7. https://doi.org/10.1200/jco.2011.38.9429.

9. So CC, Wan TS, Chow JL, Hui KC, Choi WW, Lam CC, Chan LC. A single-center cytogenetic study of 629 Chinese patients with de novo acute myeloid leukemiaevidence of major ethnic differences and a high prevalence of acute promyelocytic leukemia in Chinese patients. Cancer Genet. 2011; 204:430-8. https://doi.org/10.1016/j. cancergen.2011.06.003.
10. Enjeti AK, Tien SL, Sivaswaren CR. Cytogenetic abnormalities in de novo acute myeloid leukemia in adults: relation to morphology, age, sex and ethnicity - a single center study from Singapore. Hematol J. 2004; 5:419-25. https://doi.org/10.1038/sj.thj.6200544.

11. Slovak ML, Kopecky KJ, Cassileth PA, Harrington DH, Theil KS, Mohamed A, Paietta E, Willman CL, Head DR, Rowe JM, Forman SJ, Appelbaum FR. Karyotypic analysis predicts outcome of preremission and postremission therapy in adult acute myeloid leukemia: a Southwest Oncology Group/Eastern Cooperative Oncology Group Study. Blood. 2000; 96:4075-83.

12. O'Donnell MR, Tallman MS, Abboud CN, Altman JK, Appelbaum FR, Arber DA, Attar E, Borate U, Coutre SE, Damon LE, Lancet J, Maness LJ, Marcucci G, et al. Acute myeloid leukemia, version 2.2013. J Natl Compr Canc Netw. 2013; 11:1047-55.

13. Howlader N, Noone AM, Krapcho M, Garshell J, Miller D, Altekruse SF, Kosary CL, Yu M, Ruhl J, Tatalovich Z,Mariotto A, Lewis DR, Chen HS, Feuer EJ, Cronin KA (eds). SEER Cancer Statistics Review, 1975-2012, National Cancer Institute. Bethesda, MD, http://seer.cancer.gov/ csr/1975_2012/, based on November 2014 SEER data submission, posted to the SEER web site, April 2015.

14. Lowenberg B, Zittoun R, Kerkhofs H, Jehn U, Abels J, Debusscher L, Cauchie C, Peetermans M, Solbu G, Suciu S. On the value of intensive remission-induction chemotherapy in elderly patients of $65+$ years with acute myeloid leukemia: a randomized phase III study of the European Organization for Research and Treatment of Cancer Leukemia Group. J Clin Oncol. 1989; 7:1268-74.

15. Fenaux P, Mufti GJ, Hellstrom-Lindberg E, Santini V, Finelli C, Giagounidis A, Schoch R, Gattermann N, Sanz G, List A, Gore SD, Seymour JF, Bennett JM, et al. Efficacy of azacitidine compared with that of conventional care regimens in the treatment of higher-risk myelodysplastic syndromes: a randomised, open-label, phase III study. Lancet Oncol. 2009; 10:223-32. https://doi.org/10.1016/ s1470-2045(09)70003-8.

16. Fenaux P, Mufti GJ, Hellstrom-Lindberg E, Santini V, Gattermann N, Germing U, Sanz G, List AF, Gore S, Seymour JF, Dombret H, Backstrom J, Zimmerman L, et al. Azacitidine prolongs overall survival compared with conventional care regimens in elderly patients with low bone marrow blast count acute myeloid leukemia. J Clin Oncol. 2010; 28:562-9. https://doi.org/10.1200/jco.2009.23.8329.

17. Kim SJ, Cheong JW, Kim DY, Lee JH, Lee KH, Kim YK, Kim HJ, Song IC, Jo DY, Lee JO, Bang SM, Park J, Lee $\mathrm{JH}$, et al. Role of induction and consolidation chemotherapy in elderly acute myeloid leukemia patients. Int J Hematol. 2014; 100:141-51. https://doi.org/10.1007/ s12185-014-1617-8. 